\title{
Importance of slow vital capacity in the detection of airway obstruction*
}

\author{
Importância da capacidade vital lenta na detecção de \\ obstrução das vias aéreas
}

\author{
Ana Raquel Gonçalves de Barros, Margarida Batista Pires, \\ Nuno Miguel Ferreira Raposo
}

\begin{abstract}
Objective: To investigate the presence of airway obstruction by determining the $\mathrm{FEV}_{1} / \mathrm{FVC}$ and $\mathrm{FEV}_{1} /$ slow vital capacity (SVC) ratios. Methods: This was a quantitative, retrospective cross-sectional study. The sample comprised 1,084 individuals who underwent spirometry and plethysmography in a central hospital in Lisbon, Portugal. The study sample was stratified into six groups, by pulmonary function. Results: The analysis of the FEV/FVC ratio revealed the presence of airway obstruction in 476 individuals (43.9\%), compared with 566 individuals (52.2\%) for the analysis of the $\mathrm{FEV}_{1} / \mathrm{SVC}$ ratio. In the airway obstruction, airway obstruction plus lung hyperinflation, and mixed pattern groups, the difference between SVC and FVC (SVC - FVC) was statistically superior to that in the normal pulmonary function, reduced FEF, and restrictive lung disease groups. The SVC - FVC parameter showed a significant negative correlation with $\mathrm{FEV}_{1}$ (in \% of the predicted value) only in the airway obstruction plus lung hyperinflation group. Conclusions: The FEV $/$ SVC ratio detected the presence of airway obstruction in more individuals than did the $\mathrm{FEV}_{1} / \mathrm{FVC}$ ratio; that is, the $\mathrm{FEV}_{1} / \mathrm{SVC}$ ratio is more reliable than is the $\mathrm{FEV}_{1} /$ FVC ratio in the detection of obstructive pulmonary disease.
\end{abstract}

Keywords: Airway Obstruction; Spirometry; Plethysmography.

\section{Resumo}

Objetivo: Investigar a ocorrência de obstrução das vias aéreas por meio da relação $V_{E F} / C V F$ e da relação $V E F_{1} /$ capacidade vital lenta (CVL). Métodos: Estudo do tipo quantitativo, retrospectivo e transversal. A amostra foi constituída por 1.084 indivíduos que realizaram espirometria e pletismografia num hospital central da região de Lisboa, Portugal. A amostra foi estratificada em seis grupos funcionais respiratórios. Resultados: $A$ análise da relação $V E F_{1} / C V F$ revelou a presença de obstrução das vias aéreas em 476 indivíduos (43,9\%), enquanto a relação $V E F_{1} / C V L$ detectou a presença dessa em 566 indivíduos (52,2\%). A diferença entre a CVL e a CVF (CVL - CVF) nos grupos relativos à obstrução brônquica, à obstrução brônquica com hiperinsuflação pulmonar e à alteração ventilatória mista foi estatisticamente superior àquela encontrada nos grupos sem alteração ventilatória, com diminuição dos FEFs e com restrição pulmonar. 0 parâmetro CVL - CVF apresentou correlação negativa significativa com $\mathrm{VEF}_{1}$ em \% do previsto apenas no grupo com obstrução brônquica com hiperinsuflação pulmonar. Conclusões: $\mathrm{A}$ relação $\mathrm{VEF}_{1} / \mathrm{CVL}$ detectou a presença de obstrução das vias aéreas em um número maior de indivíduos que a relação $\mathrm{VEF}_{1} / \mathrm{CVF}$, ou seja, a relação $\mathrm{VEF}_{1} / \mathrm{CVL}$ é mais confiável na detecção de alterações ventilatórias obstrutivas.

Descritores: Obstrução das vias respiratórias; Espirometria; Pletismografia.

\footnotetext{
* Study carried out at the Portuguese Red Cross School of Health and at the Northern Lisbon Hospital Center Pulido Valente Hospital, Lisbon, Portugal.

Correspondence to: Raquel Barros. Rua Castelo dos Mouros 118A, Bairro 7 Castelos, 2785-290, São Domingos de Rana, Lisboa, Portugal.

Tel. 351 965205783. E-mail: raquel.barros@cardiocvp.net

Financial support: None.

Submitted: 24 September 2012. Accepted, after review: 18 March 2013.
} 


\section{Introduction}

In 2005, vital capacity (VC) was described by the American Thoracic Society/European Respiratory Society (ATS/ERS) ${ }^{(1)}$ as the volume of air mobilized between a maximal inspiratory maneuver and a maximal expiratory maneuver. An FVC maneuver or a slow vital capacity (SVC) maneuver can be used in order to determine VC.

When an FVC maneuver is performed, there is higher dynamic compression and airway collapse, reducing the ability to mobilize the volume of air during exhalation and therefore causing air trapping. Consequently, FVC values can be lower than SVC values; because SVC is measured through an unforced maneuver, there is less intrathoracic pressure, and, consequently, a larger volume of air can be mobilized. ${ }^{(2)}$

The factors influencing airway caliber can affect VC, principally FVC. In addition to those, other key factors should be analyzed. The determinants of TLC and RV also affect VC. Chest wall retraction, lung retraction, and the pressure resulting from respiratory muscle strength determine TLC and $\mathrm{RV} .{ }^{(3,4)}$

In healthy individuals, the difference between SVC and FVC (SVC - FVC) is practically zero; however, in the presence of airway obstruction, these differences can become apparent and are mostly related to the presence of lung hyperinflation. ${ }^{(4)}$

According to the ATS/ERS, ${ }^{(1)}$ the ratio between FEV $_{1}$ and maximal vital capacity, as measured by spirometry, can be used in order to determine the presence of airway obstruction. When pulmonary function tests are performed, analysis of the $\mathrm{FEV}_{1} / \mathrm{FVC}$ ratio is sometimes used in order to determine the presence of airway obstruction because additional respiratory maneuvers are required in order to assess TLC. This is why this parameter is often not measured and is therefore given less weight.

The primary objective of the present study was to investigate the presence of airway obstruction by determining the $\mathrm{FEV}_{1} / \mathrm{FVC}$ and $\mathrm{FEV}_{1} / \mathrm{SVC}$ ratios. A secondary objective was to determine whether the SVC - FVC parameter correlated with lung disease severity, as determined by percent predicted $\mathrm{FEV}_{1}\left(\mathrm{FEV}_{1} \%\right)$.

\section{Methods}

This was a quantitative, retrospective crosssectional study. A non-probabilistic convenience sampling procedure was used.
Data collection was performed with the use of a database belonging to the institution where the study was conducted. The database contained information on the anthropometric and pulmonary function characteristics of the individuals in the study sample.

The study sample consisted of 1,084 individuals who underwent spirometry and plethysmography on the same day (between January of 2005 and December of 2011) in a central hospital in Lisbon, Portugal.

We included individuals who were 18 years of age or older and who had undergone spirometry and plethysmography for the first time in the facility where the study was conducted. We excluded individuals who had undergone bronchodilator therapy on the day of the test and those in whom pulmonary function testing did not include determination of TLC or meet the quality criteria.

The database used in the present study contained data regarding 1,321 patients; however, 237 patients were excluded from the analysis, the final study sample therefore consisting of 1,084 patients. Of the 237 individuals who were excluded, 41 had received bronchodilator therapy on the day of the test, 103 had not undergone determination of TLC, and 93 had undergone pulmonary function tests that did not meet the quality criteria.

For the present study, we considered only the pulmonary function tests that were performed in the first visit to the laboratory; that is, subsequent follow-up visits were not studied, in order to avoid repetition of results in the same individual.

In addition to spirometry, all of the individuals underwent plethysmography, because TLC is typically measured by plethysmography in the laboratory where the study was conducted. Furthermore, the lung volume data were essential for the characterization of the patients.

In the present study, spirometry and plethysmography were performed in accordance with the ATS/ERS guidelines, having met the quality criteria thereof. ${ }^{(5,6)}$

The pulmonary function test results were interpreted in accordance with the criteria proposed by the ATS/ERS. ${ }^{(1)}$ The reference equations used in the present study have been described elsewhere. ${ }^{(7)}$

On the basis of the results of the pulmonary function tests, the study sample was divided 
into six groups. The normal pulmonary function group comprised 176 individuals; the reduced FEF group (i.e., the group of individuals with decreased FEFs at different levels of VC) comprised 225 individuals; the airway obstruction group comprised 316 individuals; the airway obstruction plus lung hyperinflation group comprised 215 individuals; the restrictive lung disease group comprised 117 individuals; and the mixed pattern group (i.e., the group of individuals with mixed obstructive and restrictive lung disease) comprised 35 individuals.

In the present study, we used a Vmax Series Autobox 6200 plethysmograph (Sensormedics, Yorba Linda, CA, USA).

For the statistical characterization of the study sample, we calculated descriptive statistics. For quantitative variables, we used measures of central tendency (sample mean), dispersion (standard deviation), and association (Spearman's correlation coefficient). For qualitative variables, we analyzed the distribution of frequencies.

In order to test the normality of data distribution, we used the Kolmogorov-Smirnov test. Because the study variables showed a non-normal distribution, we used nonparametric statistical methods.

In order to determine whether the SVC FVC parameter varied according to the type of respiratory pattern, we used the Kruskal-Wallis test. In order to identify the group (or groups) showing those differences, we used multiple comparisons of the means for independent samples.

For all statistical tests, the level of significance was set at 0.05 .

\section{Results}

The analysis of the $\mathrm{FEV}_{1} / \mathrm{FVC}$ ratio revealed the presence of airway obstruction in 476 individuals (43.9\%), compared with 566 individuals (52.2\%) for the analysis of the $\mathrm{FEV}_{1} / \mathrm{SVC}$ ratio.

Table 1 shows the anthropometric characteristics of the individuals in the study sample, divided into six groups by pulmonary function. Females predominated in the normal pulmonary function and reduced FEF groups (62\% and 68\%, respectively), whereas, in the airway obstruction, airway obstruction plus lung hyperinflation, restrictive lung disease, and mixed pattern groups, males predominated (54.7\%, $66.5 \%, 58.1 \%$ and $68.6 \%$ respectively).

Table 2 shows the pulmonary function parameters (spirometry and plethysmography) for the six groups of individuals. The differences between SVC and FVC were greater in the presence of an obstructive component, i.e., in the airway obstruction group (140.9 $\pm 9.20 \mathrm{~mL})$, in the airway obstruction plus lung hyperinflation group $(127.4 \pm 9.83 \mathrm{~mL})$, and in the mixed pattern group (134.3 $\pm 21.1 \mathrm{~mL})$.

In order to determine whether the SVC FVC parameter varied according to the type of respiratory pattern, we used the Kruskal-Wallis test, which revealed the existence of statistical differences $(p<0.001)$ in at least one of the pulmonary function groups $(p<0.001)$. In order to identify the groups showing those differences, we used multiple comparisons of the means for independent samples. The results are shown in Table 3.

Table 1 - Anthropometric characteristics of the patients under study. ${ }^{\mathrm{a}}$

\begin{tabular}{ccccccc}
\hline Variables & \multicolumn{5}{c}{ Groups } \\
\cline { 2 - 6 } & $\begin{array}{c}\text { Normal } \\
\text { pulmonary } \\
\text { function }\end{array}$ & Reduced FEF & $\begin{array}{c}\text { Airway } \\
\text { obstruction }\end{array}$ & $\begin{array}{c}\text { Airway } \\
\text { obstruction } \\
\text { with lung } \\
\text { hyperinflation }\end{array}$ & $\begin{array}{c}\text { Restrictive } \\
\text { lung disease }\end{array}$ & $\begin{array}{c}\text { Mixed } \\
\text { obstructive } \\
\text { and restrictive } \\
\text { lung disease }\end{array}$ \\
\cline { 2 - 7 }$(\mathrm{n}=176)$ & $(\mathrm{n}=225)$ & $(\mathrm{n}=316)$ & $(\mathrm{n}=215)$ & $(\mathrm{n}=117)$ & $(\mathrm{n}=35)$ \\
\hline Gender & & & & & & \\
Male & $67(38.0)$ & $72(32.0)$ & $173(54.7)$ & $143(66.5)$ & $68(58.1)$ & $24(68.6)$ \\
Female & $109(62.0)$ & $153(68.0)$ & $143(45.3)$ & $72(33.5)$ & $49(41.9)$ & $11(31.4)$ \\
Age, years & $54.3 \pm 14.5$ & $57.9 \pm 11.3$ & $61.8 \pm 13.1$ & $61.2 \pm 12.3$ & $60.1 \pm 12.6$ & $64.1 \pm 12.3$ \\
Height, $\mathrm{m}$ & $1.61 \pm 0.09$ & $1.60 \pm 0.09$ & $1.63 \pm 0.09$ & $1.64 \pm 0.09$ & $1.62 \pm 0.10$ & $1.65 \pm 0.08$ \\
Weight, $\mathrm{kg}$ & $72.6 \pm 15.7$ & $74.8 \pm 15.8$ & $75.7 \pm 15.4$ & $71.1 \pm 15.8$ & $74.7 \pm 15.6$ & $76.2 \pm 16.2$ \\
BMl, $\mathrm{kg} / \mathrm{m}^{2}$ & $28 \pm 5$ & $29 \pm 6$ & $28 \pm 5$ & $26 \pm 6$ & $28 \pm 6$ & $28 \pm 5$ \\
\hline
\end{tabular}

BMl: body mass index. ${ }^{2}$ Values expressed as $n(\%)$ or as mean \pm SD. 
In the airway obstruction, airway obstruction plus lung hyperinflation, and mixed pattern groups, the SVC - FVC parameter was statistically superior to that in the normal pulmonary function, reduced FEF, and restrictive lung disease groups $(p<0.05$; Table 3). In terms of the SVC - FVC parameter, there were no significant differences among the airway obstruction, airway obstruction plus lung hyperinflation, and mixed pattern groups ( $p \geq$ 0.05 for all) or among the normal pulmonary function, reduced FEF, and restrictive lung disease groups ( $p \geq 0.05$ for all; Table 3 ).

Table 4 shows Spearman's correlation coefficients for the correlations between the

Table 2 - Pulmonary function characteristics of the patients under study. ${ }^{\text {a }}$

\begin{tabular}{|c|c|c|c|c|c|c|}
\hline \multirow[t]{3}{*}{ Variables } & \multicolumn{6}{|c|}{ Groups } \\
\hline & $\begin{array}{c}\text { Normal } \\
\text { pulmonary } \\
\text { function }\end{array}$ & Reduced FEF & $\begin{array}{c}\text { Airway } \\
\text { obstruction }\end{array}$ & $\begin{array}{c}\text { Airway } \\
\text { obstruction } \\
\text { with lung } \\
\text { hyperinflation }\end{array}$ & $\begin{array}{l}\text { Restrictive } \\
\text { lung disease }\end{array}$ & $\begin{array}{c}\text { Mixed } \\
\text { obstructive } \\
\text { and restrictive } \\
\text { lung disease }\end{array}$ \\
\hline & $(n=176)$ & $(n=225)$ & $(n=316)$ & $(n=215)$ & $(n=117)$ & $(n=35)$ \\
\hline $\mathrm{FEV}_{1}, \mathrm{~L}$ & $2.78 \pm 0.05$ & $2.30 \pm 0.04$ & $1.90 \pm 0.04$ & $1.33 \pm 0.04$ & $1.90 \pm 0.05$ & $1.17 \pm 0.07$ \\
\hline $\mathrm{FEV}_{1}, \%$ & $109.5 \pm 1.03$ & $95.9 \pm 0.74$ & $74.8 \pm 0.99$ & $51.0 \pm 1.17$ & $75.8 \pm 1.61$ & $45.8 \pm 2.65$ \\
\hline FVC, L & $3.43 \pm 0.07$ & $3.07 \pm 0.05$ & $3.04 \pm 0.06$ & $2.68 \pm 0.05$ & $2.38 \pm 0.07$ & $1.92 \pm 1.16$ \\
\hline FVC, \% & $111.3 \pm 1.16$ & $105.4 \pm 0.91$ & $96.4 \pm 1.06$ & $82.3 \pm 1.28$ & $76.3 \pm 1.45$ & $59.5 \pm 3.31$ \\
\hline SVC, L & $3.51 \pm 0.07$ & $3.14 \pm 0.06$ & $3.18 \pm 0.05$ & $2.81 \pm 0.06$ & $2.45 \pm 0.07$ & $2.06 \pm 0.12$ \\
\hline SVC, \% & $110.0 \pm 1.18$ & $103.6 \pm 0.87$ & $97.4 \pm 1.00$ & $82.5 \pm 1.30$ & $75.9 \pm 1.46$ & $61.5 \pm 3.20$ \\
\hline SVC - FVC, mL & $79.3 \pm 7.61$ & $74.5 \pm 14.3$ & $140.9 \pm 9.20$ & $127.4 \pm 9.83$ & $78.0 \pm 9.41$ & $134.3 \pm 21.1$ \\
\hline $\mathrm{FEV}_{1} / \mathrm{FVC}, \%$ & $81.5 \pm 0.29$ & $75.3 \pm 0.24$ & $62.6 \pm 0.48$ & $49.4 \pm 0.73$ & $80.2 \pm 0.57$ & $61.3 \pm 1.30$ \\
\hline $\mathrm{FEV}_{1} / \mathrm{SVC}, \%$ & $79.7 \pm 0.34$ & $73.8 \pm 0.28$ & $59.4 \pm 0.47$ & $47.2 \pm 0.73$ & $77.5 \pm 0.63$ & $57.0 \pm 1.25$ \\
\hline $\mathrm{RV}, \mathrm{L}$ & $1.64 \pm 0.42$ & $1.83 \pm 0.43$ & $2.35 \pm 0.59$ & $3.86 \pm 0.95$ & $1.39 \pm 0.43$ & $1.88 \pm 0.50$ \\
\hline $\mathrm{RV}, \%$ & $87.8 \pm 18.9$ & $96.6 \pm 20.7$ & $111.8 \pm 20.0$ & $180.3 \pm 36.3$ & $67.4 \pm 17.8$ & $86.3 \pm 29.0$ \\
\hline TLC, L & $5.16 \pm 1.05$ & $4.97 \pm 1.01$ & $5.53 \pm 1.19$ & $6.67 \pm 1.22$ & $3.84 \pm 0.93$ & $3.94 \pm 0.91$ \\
\hline TLC, \% & $98.7 \pm 11.5$ & $97.6 \pm 11.2$ & $99.8 \pm 10.7$ & $117.0 \pm 14.6$ & $70.0 \pm 9.16$ & $68.7 \pm 16.3$ \\
\hline RV/TLC & $32.4 \pm 7.76$ & $37.4 \pm 7.47$ & $43.1 \pm 9.36$ & $57.9 \pm 9.08$ & $36.9 \pm 9.71$ & $48.5 \pm 9.75$ \\
\hline FRC, L & $2.51 \pm 0.62$ & $2.59 \pm 0.63$ & $3.18 \pm 0.75$ & $4.64 \pm 1.07$ & $2.04 \pm 0.54$ & $2.48 \pm 0.59$ \\
\hline FRC, $\%$ & $87.7 \pm 16.9$ & $91.6 \pm 17.2$ & $104.2 \pm 16.4$ & $148.0 \pm 25.0$ & $67.1 \pm 12.2$ & $78.5 \pm 19.6$ \\
\hline
\end{tabular}

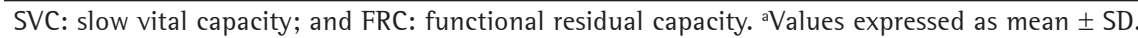

Table 3 - Comparison of the means of the differences between slow vital capacity and FVC among the pulmonary function groups under study.

\begin{tabular}{|c|c|c|c|c|c|c|}
\hline \multirow[t]{3}{*}{ Groups } & \multicolumn{6}{|c|}{ Groups } \\
\hline & $\begin{array}{l}\text { Normal } \\
\text { pulmonary } \\
\text { function }\end{array}$ & $\begin{array}{l}\text { Reduced } \\
\text { FEF }\end{array}$ & $\begin{array}{c}\text { Airway } \\
\text { obstruction }\end{array}$ & $\begin{array}{c}\text { Airway } \\
\text { obstruction } \\
\text { with lung } \\
\text { hyperinflation }\end{array}$ & $\begin{array}{l}\text { Restrictive } \\
\text { lung disease }\end{array}$ & $\begin{array}{c}\text { Mixed } \\
\text { obstructive } \\
\text { and restrictive } \\
\text { lung disease }\end{array}$ \\
\hline & $\mathrm{p}$ & $\mathrm{P}$ & $p$ & $p$ & $p$ & $p$ \\
\hline $\begin{array}{l}\text { Normal pulmonary } \\
\text { function }\end{array}$ & $\mathrm{N} / \mathrm{A}$ & 0.103 & $<0.001$ & $<0.001$ & 0.922 & 0.002 \\
\hline Reduced FEF & 0.103 & $\mathrm{~N} / \mathrm{A}$ & $<0.001$ & $<0.001$ & 0.181 & $<0.001$ \\
\hline Airway obstruction & $<0.001$ & $<0.001$ & N/A & 0.647 & $<0.001$ & 0.336 \\
\hline $\begin{array}{l}\text { Airway obstruction with } \\
\text { lung hyperinflation }\end{array}$ & $<0.001$ & $<0.001$ & 0.647 & $\mathrm{~N} / \mathrm{A}$ & 0.001 & 0.245 \\
\hline Restrictive lung disease & 0.922 & 0.181 & $<0.001$ & 0.001 & $\mathrm{~N} / \mathrm{A}$ & 0.002 \\
\hline $\begin{array}{l}\text { Mixed obstructive and } \\
\text { restrictive lung disease }\end{array}$ & 0.002 & $<0.001$ & 0.336 & 0.245 & 0.002 & $\mathrm{~N} / \mathrm{A}$ \\
\hline
\end{tabular}

Kruskal-Wallis test for independent samples for multiple comparisons of the means. 
Table 4 - Spearman's correlation coefficients for the correlations of the difference between slow vital capacity and FVC with $\mathrm{FEV}_{1}$ (in \% of the predicted value).

\begin{tabular}{|c|c|c|c|c|c|c|c|c|c|c|c|}
\hline \multicolumn{12}{|c|}{ Groups } \\
\hline \multicolumn{2}{|c|}{$\begin{array}{c}\text { Normal } \\
\text { pulmonary } \\
\text { function }\end{array}$} & \multicolumn{2}{|c|}{ Reduced FEF } & \multicolumn{2}{|c|}{$\begin{array}{c}\text { Airway } \\
\text { obstruction }\end{array}$} & \multicolumn{2}{|c|}{$\begin{array}{c}\text { Airway } \\
\text { obstruction } \\
\text { with lung } \\
\text { hyperinflation }\end{array}$} & \multicolumn{2}{|c|}{$\begin{array}{c}\text { Restrictive lung } \\
\text { disease }\end{array}$} & \multicolumn{2}{|c|}{$\begin{array}{c}\text { Mixed } \\
\text { obstructive and } \\
\text { restrictive lung } \\
\text { disease }\end{array}$} \\
\hline$r$ & $p$ & $r$ & $\mathrm{p}$ & $r$ & $\mathrm{p}$ & $r$ & $p$ & $r$ & $\mathrm{p}$ & $r$ & $p$ \\
\hline 0.027 & 0.719 & -0.719 & 0.292 & -0.049 & 0.384 & -0.156 & 0.022 & -0.025 & 0.790 & 0.089 & 0.615 \\
\hline
\end{tabular}

SVC - FVC parameter and $\mathrm{FEV}_{1} \%$, the latter being the parameter characterizing lung disease severity. The SVC - FVC parameter was found to correlate significantly with lung disease severity $(p<0.05)$ only in the airway obstruction plus lung hyperinflation group.

\section{Discussion}

In the present study, the $\mathrm{FEV}_{1} / \mathrm{SVC}$ ratio detected the presence of airway obstruction in more individuals than did the $\mathrm{FEV}_{1} / \mathrm{FVC}$ ratio. The former ratio detected the presence of airway obstruction in $52.2 \%$ of the sample as a whole, compared with $43.9 \%$ for the latter ratio. This means that there was a discrepancy of $8.4 \%$ between the two ratios.

Studies by Chhabra ${ }^{(8)}$ and Rasheed et al ${ }^{(9)}$ also examined the use of the $\mathrm{FEV}_{1} / \mathrm{FVC}$ ratio or the $\mathrm{FEV}_{1} / \mathrm{SVC}$ ratio as a criterion for the presence of airway obstruction. The study by Chhabra ${ }^{(8)}$ showed that the differences among the $\mathrm{FEV}_{1} /$ FVC, $\mathrm{VEF}_{1}$ /expiratory VC, and FEV/inspiratory $\mathrm{VC}$ ratios in healthy individuals and in those with mild obstruction were not significant; however, those differences were statistically significant in individuals with at least moderate obstruction.

The study by Rasheed et al..$^{(9)}$ examined two groups of individuals, grouped by underlying disease process (asthma or COPD), and showed a discrepancy between the FEV $/$ SVC and FEV ${ }_{1}$ / FVC ratios in $17 \%$ of the sample as a whole; in the asthma and COPD groups, this discrepancy was observed in 22\% and 13\% of the patients, respectively.

In the present study, we performed a sub-analysis based on the respiratory pattern. The analysis showed that the differences between SVC and FVC (SVC - FVC) were greater in the presence of airway obstruction, a finding that is consistent with those of Chan and Irvin, ${ }^{(2)}$ who reported that, in the presence of airflow limitation, the differences between the two variables are greater.

These results might be due to the fact that FVC maneuvers are forced maneuvers and can cause small airway collapse, therefore leading to an underestimation of this variable.

The greatest discrepancy in volumes between SVC and FVC occurred in the airway obstruction, airway obstruction plus lung hyperinflation, and mixed pattern groups. This might explain why the $\mathrm{FEV}_{1} / \mathrm{FVC}$ ratios were higher than the $\mathrm{FEV}_{1}$ I SVC ratios in the present study. This is due to the fact that the denominator of the former ratio is lower than is that of the latter ratio, which therefore has greater airway obstruction detection capability.

In one study, ${ }^{(10)}$ SVC - FVC was reported to be greater in individuals with asthma than in healthy individuals, being also greater in the presence of airway obstruction and increasing with the degree of respiratory disease severity. These findings are consistent with those in the study by Kawakami et al., ${ }^{(11)}$ in which SVC values were higher than FVC values in individuals with COPD.

In the airway obstruction, airway obstruction plus lung hyperinflation, and mixed pattern groups, the SVC - FVC parameter was found to be statistically superior to that in the normal pulmonary function, reduced FEF, and restrictive lung disease groups. This was due to the presence of an obstructive component in the first three groups. Therefore, it appears that the presence of obstruction is responsible for the differences found in the present study.

According to the ATS/ERS, (1) the degree of lung disease severity is characterized by $\mathrm{FEV}_{1} \%$, which is habitually used in order to determine disease severity in patients with obstructive lung disease, restrictive lung disease, or mixed 
obstructive and restrictive lung disease. Therefore, in order to determine whether the differences between SVC and FVC were correlated with the severity of lung disease, we analyzed the correlation between the SVC - FVC parameter and $\mathrm{FEV}_{1} \%$.

The SVC - FVC parameter showed a significant negative correlation with $\mathrm{FEV}_{1} \%$ only in the airway obstruction plus lung hyperinflation group. The results obtained suggest that the severity of lung disease cannot be explained by the differences observed, given that only one of the groups showed significant results.

The present study showed that the differences between SVC and FVC have statistical significance, the volumes obtained by unforced maneuvers being greater than those obtained by forced maneuvers. The differences between the two parameters were greater in the presence of an obstructive component, and our correlation analysis revealed that the differences increased as the degree of severity increased in the airway obstruction plus lung hyperinflation group.

The present study showed that the FEV $/$ SVC ratio detected the presence of airway obstruction in more individuals than did the FEV/FVC ratio, given that the VC volume obtained by an SVC maneuver is greater than is that obtained by an FVC maneuver.

The present study allowed us to conclude that the use of the FEV /SVC ratio in the detection of airway obstruction does not underestimate the results of VC, therefore increasing the sensitivity of pulmonary function tests in the diagnosis of airway obstruction and avoiding interpretation errors that can prevent the initiation of appropriate therapeutic measures.

\section{References}

1. Pellegrino R, Viegi G, Brusasco V, Crapo RO, Burgos F, Casaburi R, et al. Interpretative strategies for lung function tests. Eur Respir J. 2005;26(5):948-68. http://dx.doi. org/10.1183/09031936.05.00035205 PMid:16264058

2. Chan ED, Irvin CG. The detection of collapsible airways contributing to airflow limitation. Chest. 1995;107(3):856-9. http://dx.doi.org/10.1378/ chest.107.3.856

3. Brusasco V, Pellegrino R, Rodarte JR. Vital capacities in acute and chronic airway obstruction: dependence on flow and volume histories. Eur Respir J. 1997;10(6):131620. http://dx.doi.org/10.1183/09031936.97.10061316 PMid:9192935

4. Constán EG, Medina JP, Silvestre AH, Alvarez 11, Olivas RB. Difference between the slow vital capacity and forced vital capacity: predictor of hyperinflation in patients with airflow obstruction. The Internet Journal of Pulmonary Medicine. 2005;4(2):1.

5. Miller MR, Hankinson J, Brusasco V, Burgos F, Casaburi R, Coates A, et al. Standardisation of spirometry. Eur Respir J. 2005;26(2):319-38. http://dx.doi.org/10.118 3/09031936.05.00034805 PMid:16055882

6. Wanger J, Clausen JL, Coates A, Pedersen OF, Brusasco $\mathrm{V}$, Burgos F, et al. Standardisation of the measurement of lung volumes. Eur Respir J. 2005;26(3):511-22. http:// dx.doi.org/10.1183/09031936.05.00035005 PMid:16135736

7. Quanjer PH. Standardized lung function testing. Bull Eur Physiopathol Respir. 1983;19(Suppl 5):1-95.

8. Chhabra SK. Forced vital capacity, slow vital capacity, or inspiratory vital capacity: which is the best measure of vital capacity? J Asthma. 1998;35(4):361-5. http:// dx.doi.org/10.3109/02770909809075669 PMid:9669830

9. Rasheed A, Vasudevan V, Shahzad S, Arjomand DM, Reminick S. Underdiagnosis of obstructive disease by spirometry. Chest. 2011;140(4):691A. http://dx.doi. org/10.1378/chest.1118407

10. Cohen J, Postma DS, Vink-Klooster K, van der Bij W, Verschuuren E, Ten Hacken NH, et al. FVC to slow inspiratory vital capacity ratio: a potential marker for small airways obstruction. Chest. 2007;132(4):1198-203. http://dx.doi.org/10.1378/chest.06-2763 PMid:17890480

11. Kawakami Y, Kishi F, Dohsaka K, Nishiura Y, Suzuki A. Reversibility of airway obstruction in relation to prognosis in chronic obstructive pulmonary disease. Chest. 1988;93(1):49-53. http://dx.doi.org/10.1378/ chest.93.1.49 PMid:3335167

\section{About the authors}

\section{Ana Raquel Gonçalves de Barros}

Professor. Portuguese Red Cross School of Health; and Cardiology; and Pulmonology Technician. Northern Lisbon Hospital Center Pulido Valente Hospital, Lisbon, Portugal.

\section{Margarida Batista Pires}

Cardiology and Pulmonology Technician. Portuguese Red Cross School of Health, Lisbon, Portugal.

\section{Nuno Miguel Ferreira Raposo}

Professor. Portuguese Red Cross School of Health; and Cardiology and Pulmonology Technician. Western Lisbon Hospital Center Santa Cruz Hospital, Lisbon, Portugal. 